\title{
積雪寒冷地における住宅室内環境の現在 〜熱空気環境はどこまで改善されたか〜
}

\section{Nowadays of Indoor Environment of Residential Houses in Snowy Region - From the Viewpoint of Indoor Thermal Environment and Indoor Air Quality -}

数年前に積雪寒冷地の住宅における室内環境問題 を明確にするため，本誌において特集「積雪寒冷地 における室内環境問題の過去・現在・未来」（日本 雪工学会誌1997年 1 月号, Vo.13, No.1, ) を企画し た。当時，住宅の室内環境に対する快適性や省工ネ ルギー性への関心が高まりつつあり，また，積雪寒 冷地の住宅設計のあり方を整理する必要があったた め，建物の環境委員会が中心となってとりまとめた。 その後, 地球環境問題の顕在化, 住まい手の快適性 の追求，住宅省エネルギー基準の強化，シックハウ ス問題の関心の高まり，そ狆に続くいわゆるシック ハウス法の制定，等の動きがあり，住宅を取り巻く 状況は大きく変化した。

積雪寒冷地の住宅が抱える室内環境問題としては, 冬期における不十分な暖房環境，非暖房室の極めて 低い室温, 結露・カビの発生等が指摘される。結露 発生の主な原因は壁表面温度が低いことであるが, $\mathrm{RC}$ コンクリート造の集合住宅では換気量が少なく, 室内の湿気が外に排出さ㧈にくいことも原因の一つ となっている。これらの問題はいずれも，住宅の快 適性を損なうのみならず，住まい手の健康に悪い影 響を与える可能性が高い。例えば，室内に温度差が あることにより，暖房室より非暖房室へ移動した際 に，居住者は生理的なストレスを受けるため血圧の 上昇を招き，さらには脳卒中を引き起こす要因とな る。また, 結露発生はカビの繁殖を促進し, 壁やカ一 テンを污損するような問題のほか，空気に浮遊する
カビ胞子が様々な健康被害を引き起こす可能性があ る。

このような問題を防除するためには，内と外とを 明確に区別する必要があり，住宅の断熱・気密性の 確保がその有効な手法である。断熱・気密性を高め ることは，同時に，最適な暖房設備ならびに換気設 備の設置とそれらの適切な使用が求められることに なる。これら，断熱・気密・暖房・換気がバランス 良く計画されれば，換気不足による室内空気の污染 や，気密施工が不十分なために生じる壁体内部結露， 不十分な暖房による非暖房スペースにおける結露・ カビの被害等の問題を排除することができる。

住宅建設に関わる設計者，ハウスメーカー，工務 店，行政担当者においては，積雪寒冷地特有の室内 環境問題を把握した上で, 断熱・気密化の意義を十 分に理解し，正しい施工法を実施することが望まれ る。また，居住者（エンドユーザー）においては， 断熱・気密化された住宅における正しい住まい方を 知る必要がある。気密化された住宅で開放型の燃焼 器具を用いれば当然, 室内空気污染や結露発生の原 因となるし，暖房温度をある程度確保しなければ結 露が生じてしまう。

最近，住宅の断熱・気密化の必要性は広く知られ るようになり，そ扎に伴い，冬期における室内環境 問題もひと昔前と比べて改善されているのではない かと期待される。しかし，一方で，結露問題や住宅 の気密化による室内空気污染の問題，不十分な暖房

* 東北工業大学 教授 
環境など，未だに解決されない状況が存在している ことも䀣念される。そこで，本特集では，「積雪寒 冷地における住宅公内環境の現在 〜熱空気環境は どこまで改善されたか〜」と題して，ここ数年の間 に, どの程度, 断熱・気密化が進んでいるのか, 室 内環境問題はどの程度改善されたかに焦点を当て, 積雪寒冷な地域において積極的に活動されている方々 より最新の状況を報告していただく。一言で積雪寒 冷地といっても, 北海道から東北, 北陸地方まで, それぞれが置かれている状況は異なっている。この 特集を通じて，各地域が今後，取り組むべき課題を 明らかにすることができれれ゙幸いである。

建物の環境委員会では様々な機会を通じて，この ような情報を発信し，啓発活動を積極的に行ってい る。雪工学会の会員にも室内環境の問題に対して関 心をもっていただくことを意図し，建物の環境委員 会が企画した。少しでも室内環境の向上に慗がるこ とを願っている。
題目と執筆者はそれぞれ以下の通りである。

(1)主旨説明

石川 善美（東北工業大学）

(2)居住環境の20年間の変化

石川 善美（東北工業大学）

長谷川兼一（秋田県立大学）

吉野＼cjkstart博（東北大学大学院）

(3)シックハウス問題の現状

天野健太郎・吉野＼cjkstart博（東北大学大学院）

(4)北海道における新築住宅の仕梯と室内環境

長谷川寿大（北海道大学大学院）

(5)集合住宅における結露問題一青森県の例

澤田＼cjkstart紘次（八戸工業大学）

(6)岩手県住宅の冬季室内環境の現状

佐々木 隆 (岩手県立大学)

(7)住宅におけるカビ量一東北地方の例一

長谷川兼一（秋田県立大学）

(8)新潟県の住宅における室内温熱環境とエネルギー 消費量

赤林 伸一（新潟大学大学院）

山岸 明浩 (県立新潟女子短期大学)

(9)富山・石川・福井における住宅熱空気環境調査の 事例

垂水弘夫・西村 仁（金沢工業大学）

(10)住宅におけるエネルギー消費量と二酸化炭素排出 量の推移

三浦 秀一 (東北芸術工科大学) 